\title{
Fairy Beliefs and other Folklore Notes from County Leitrim
}

\section{Leland L. Duncan F. S. A.}

To cite this article: Leland L. Duncan F. S. A. (1896) Fairy Beliefs and other Folklore Notes from County Leitrim, Folklore, 7:2, 161-183, DOI: 10.1080/0015587X.1896.9720352

To link to this article: http://dx.doi.org/10.1080/0015587X.1896.9720352

巴nublished online: 14 Feb 2012.

Submit your article to this journal $\sqsubset$

Џ Article views: 1

Q View related articles $\sqsubset$

Citing articles: 1 View citing articles 5 
Mr. Leland L. Duncan read a paper entitled. "Fairy Beliefs and other Folklore Notes from County Leitrim." In the discussion which followed, the President, the Rev. $\Lambda$. Löwy, and Messrs. Gomme, Nutt, Brabrook, Kirby, Naake, Green, and Baverstock took part.

On the motion of the President a vote of thanks was passed to Mr. Duncan.

The following additions to the library were reported: Transactions of the Cymmrodorion Society, 1894-95 presented by the Society; Saga-Book of the Viking Club, Vol.I., Part I., presented by the Club; Segnius Irritant: or Eight Primitive Folklore Stories, by Mr. W. W. Strickland, presented by the author; Lucifer, March, 1895, presented by Mr. W. F. Kirby; Revue des Traditions populaires, December, 1895, January and February, 1896, presented by, the Societe.

\section{FAIRY BELIEFS AND OTHER FOLKLORE NOTES FROM COUNTY LEITRIM.}

BY LELAND L DUNCAN, F.S.A.

IN the early part of last year the attention of folklorists was directed to a criminal case in co. Tipperary which brought prominently before the public certain aspects of the Irish fairy belief. The discussion to which this case gave rise had not quite subsided when I had occasion to visit the parish of Kiltubbrid in co. Leitrim in the autumn, and it occurred to me that a collection embodying the ideas current there on the subject would be acceptable to the members of this Society. Like many other collections of folklore there are several items here the exact point of 


\section{I62 Fairy Beliefs and other Folklore Notes}

which, or their value to the science, is not quite apparent. I have thought it best however to include all such, in the hope that when these Leitrim fragments come to be considered side by side with those from other parts of Ireland they may yet drop into their proper places.

To the question "Who are the fairies?"I have locally met, so far, with but one answer:- "They are the fallen angels;" and consequently the traditions of the people do not give much assistance to us in discussing the various theories which have been advanced on the subject. The fairies are said to be everywhere, just as they were cast from heaven-in the air, in the water, on the earth, under the earth. Their hope of salvation at the last prompts them to acts of kindness which otherwise would not be committed, and this is the basis of not a few stories ( $c f$. Folk-Lore, vol. v. p. 182, "The first turf-fire"). According to the popular chronology the giants are stated to have been early possessors of the land but to have been driven out by the good people (Folk-Lore, vol. v. p. I78), who presumably held possession till the coming of the Danes, who had superior knowledge, and were able to defeat them.

With regard to the fairies themselves it should be noted that in the minds of the people they are always conceived of as beings of the same size as ordinary mortals, but with power to change their shape for any special purpose. They are also able to pass through such barriers as doors and walls, as one of the men explained to me, "Sure, Sir, they're like spirits." I think this point is one of great importance, as in the event of its being clearly proved to be the view held by the Celtic races generally, theories which have been built on the diminutive stature of fairies being a reminiscence of a small pre-Celtic people will, at least, have to be re-stated.

Prominent in the fairy creed of the people is that which was the central feature of the Clonmel case, viz. the belief in changelings. So far I have not been successful in dis. 
covering the reason assigned locally for this theft of mortals by the good people. Infants are the subjects of the majority of published tales of changelings; but they are by no means the only human beings taken away, no one being really safe. Good-looking people and people with kind hearts are much sought after, and midwives are also specially followed for that purpose. The reason given for so many persons escaping is that everyone is supposed to have a friend amongst the fairies who sees that no harm comes to one.

With regard to young children I have noted the following:-The night that a child is born the husband is not allowed to leave the house, as the fairies are watching round to take the infant; " but as long as the husband's breath is in the house they can do no harm." If children in arms are met, they should be spat on or around, to keep off the fairies. If you have a cross or peevish child, or one that from being in good health becomes sickly, and you have reason to believe it is a fairy child, the following plan may be tried in order to ascertain whether this is the case. Take lusmore (fox-glove) and squeeze the juice out. Give the child three drops on the tongue, and three in cach ear. Then place it at the door of the house on a shovel (on which it should be held by some one), and swing it out of the door on the shovel three times, saying: "If you'rc a fairy away with you !" If it is a fairy child, it will die that night; but if not, it will surely begin to mend.

When you have passed the dangerous period of early childhood, you are still to be ever on the watch against fairy tricks. It is not safe, for instance, after dark to call anyone by name. To do so gives the fairics power over the person called. Further, at night, it is not safe to answer a call until it has been repeated threc times, be-

I Since writing the above, I have been informed by a woman from Drum. keetan that the fuiries take human beings because they think it will aid their salvation at the Day of Judgment to have good Christians amongst them. 


\section{I64 Fairy Beliefs and other Folklore Notes}

cause, should it be a fairy calling, to answer places one in their power. Fairies can repeat a call twice, but not three times. Again, if you have your hair washed, you must eat or drink something when it is dry before you go to bed, or the fairies can take you away.

The following changeling story was told me by Mary Carty of Drumkeeran, who stated that she had always heard it related as a fact :-

There was a girl living at Kilbride, three miles from Drumkeeran, and she went one day in harvest to mind a baby for a neighbour who was out getting hay, and she was there some time rocking the child. She got sick and cross that night, and she was that way for three years. She used to tell the people to come to her at sunset, and she would tell them about their people who were dead; and she said she could show them a certain priest who had died, riding about on a white horse; but the people were afraid to go and see the sight. There was a little boy to whom she took a great liking, and would have showed him more than anyone, only he was kept from her. At the end of three years she got very bad and sick one night, and said goodbye to the people, and said she had to be going to a place called Kilbride near Dublin, that there was a redhaired boy to be taken and she had to be there, and as she was going she would tell them how to get back their own. The mother was to go to a certain little byre upon a hill between twelve and one o'clock at night, to cut a drain round the byre with a black-hafted knife, to get a lot of hens' dirt and mix it up, and between twelve and one to stand inside the byre and throw three dashes of the dirt out of the door; and when that was done she was to shout. The mother did this, and then came home; and in the morning it was their own daughter that got up and began to tell them about people who were dead. She asked for a drink; and when her mother gave it to her she forgot all about the three years and began to talk as of yesterday and minding the child. 
Here is another changeling story :-

\section{The Fairy Blacksmith.}

There was a poor man in co. Leitrim, and he had a sickly son, who was a fine boy in the commencement till he was about three years of age, when he got ill and donny; and and they couldn't know what was the cause. He remained so for four or five years more, and gave all sorts of annoyance to his poor mother and father, screeching and screaming for a thing to eat at all times.

One day his father went to the forge to get his loy irons laid with the smith. It happened that the smith did one iron remarkably well, and there was a flaw in the other, but the man never noticed it. When he came home with the irons, "Daddy," says the sickly little lad, "show me them irons." "What do you know about irons?" says the father. He still persevered to look at them; and to please him, his mother handed them to him. The lad looked at them: "Daddy," says he, "this is a good one, but that one is no good; did he throw those two irons on the ground when he did them?" "No" says the father; "he gave me this one in my hand, and he threw the other one on the floor." "The one he threw on the floor," says the little lad, "is a good one: but the one he gave you in your hand is cracked, and nearly broken; and that's the reason he handed it to you, because he knew it wouldn't sound clear on the floor. Go back with it now, and tell him it's a bad iron, and to make it better for you."

The father went back again to the smith with the iron and said: "Why did you give me a broken iron, and didn't do it right for me?" "Who told you that?" says the smith. " $\Lambda$ small little child $I$ have of my own; and he said that because it was bad you handed it into my hand, and the good one you threw on the floor to me."

"Who told you that?" says the smith.

YOL. VII. 


\section{I66 Fairy Beliefs and other Folklore Notes}

"Isn't it the case?" says he.

"Well," says the smith, "whoever told you that is as good a blacksmith as I am, and if I knew who told you, I would give you five pounds; because it is a league among all blacksmiths."

Says the man: "It's a sickly little child of my own."

"Well, if he is," says the smith, "he's as good a black. smith as me."

So the man was not thankful to him to say his child would be a fairy.

"Well," says the smith, "stop here till it bees dark, and surely your wife will begin to scold you for stopping out so late. Tell them you could be home half-an-hour sooner, or an hour, but that you were surprised looking at the fort above the house on fire, and that it's all consumed."

So he went home: and the wife began: "What kept you out so late? You have your whole day spent with them two irons now." "I could be home sooner," says he; "but I was surprised to see the fort on fire, and now it's all con. sumed. I stood an hour looking at it."

"My word!" says the lad in the cradle, "my bellows and tools are all burnt," and out with him, and ho never came back.

Barney Wuglan, Dhincy.:

If the fairies have a man carried away, he can be recovered; if seen, by a compound of strong urine and hens' excrement being thrown over him. The excrement of hens is said to be particularly efficacious in dispelling fairy enchantments. The reason given is that these birds belonged to the Danes, who were able to beat the fairies. The people also sayi that when the Danes quitted Ireland they left the hens behind to be an annoyance to any people who should inhabit the country. This character they fully maintain according to popular tradition, which asserts that if hens are left alone in a house, they will always endeavour to 
scratch straw, \&c.; into the fire, in order to burn it down, and in many other ways, such as picking off the thatch, they make themselves a nuisance. Hens when asleep droop their wings, and it is a common saying, "They are off to Denmark."

The following legend connected with the townland of Aghnahoo (field of the cave), in the parish of Kiltubbrid, again brings the Danes before us; but would at the same time seem to connect them with the fairies. It will be remembered that the suggestion has been made that these legends of the Danes are the result of their being confused in the minds of the people with the Tuatha De Danann.

\section{A Legend of Aghnahoo.}

There was an Irishman who lived in Aghnahoo, in the co. Leitrim, and he went to Denmark to look for employment. Ife went into a house in which lived an old ancient Dane, who was in the battle of Clontarf, fighting against King Brian Borroo. The old Dane was blind, and when he heard the man asking employment he says: "Are you an Irishman?"

"I am," says.he.

"What part of Ireland did you live in?"

"I lived in co. Leitrim."

"In what place?" says the Dane.

"In the townland of Aghnahoo."

"Come up," says he, "till I shake hands with you, for l'm happy to see you or any man from Ireland."

"Don't give your hand," says the girl who was taking care of the old man, "for if you do he'll hurt you." There was a cow's hough on the floor, the meat was gone, and there was nothing but the bone. The Irishman takes it up and laands it to the Dane for his hand, and the old man gave it such a warm squecze that he smashed the bone. 
"Did I hurt you?" says the Dane: "No," says he, "though you gave me a very warm squeeze." "I see," says the blind man, "that you're a very courageous man, and if you'd be so good as to go back to your own place in that land you'll find a fort." "I know it well," says the lad. Says the Dane: "When you go, kill a calf or sheep, or some animal, and when you take the skin off drag it round the little rock two or three times, and there'll come out a greyhound to you to eat the carcase. Strike her with this ball"-giving him a ball-"and if you don't strike her with it she'll be apt to tear you. The greyhound will run in when you hit her, and there'll come out a beautiful lady to you. She'll ask you: 'Who gave you the ball you hit me with?' and you'll say: 'I was in Denmark and an old Dane told me to come here and you'd give me the white rabbit that's in the press, and he gave me that ball to hit you with.'"

The man did this; and when she came out, he told her as the old Dane had said. Then she said: "I know well, for he is my father. Come in now, and I will send the rabbit to him." So when he went into the rock it was a beautiful castle inside; and he saw plenty of gold and silver, which he was wishing to have if he could. She asked him how her father was; and he said he didn't know much, but that he was still alive, rocking in the cradle, and he blind, as he believed, with age. "Dear me," says she, "it's many a long year since he left me here, and I never got any account from him before. I must obey his orders, although that rabbit is a great favourite of mine."

So she gave him the rabbit; and he set off with it to the old Dane; and when he came to him the old man asked him: "Did you come from Ireland? Did you do what I told you, or did you see my daughter?" "I did," says he. "I hope she sent me the white rabbit." "She did; here it is in this cage."

The Dane opened the cage, and took the rabbit, and 


\section{from County Leitrim.}

ordered the cook to kill it for dinner. The cook did so, and cooked it for the old Dane, and when he ate and drank plenty of the rabbit and broth, he says to the Irishman: "I promised to pay you well when you'd return with the white rabbit." "Well, you did," says the Irishman; "and I hope you'll keep your word."

"Come," he says, "and take this piece of rabbit you brought me." The Irishman took the leg of the rabbit; and when he ate it he was in great surprise; for he saw all his own country beyant in Ireland; it was as plain to him as if he was walking round every place he saw. He saw the rocks of Aghnahoo and all the pots and crocks of gold hid down at the butt of every bush that was in it.

"Are you well paid?" says the Dane.

"I am," says he, "and overpaid, and I am thankful to you, for I'll never be a poor man when I go home."

"Now," says the Dane, "take a sup of the soup and you'll see more."

The Irishman was so greedy to see more, he drank the spoonful of soup, and every hate ever he saw vanished from his eyes; and he never saw either money or bushes, and he could never find where the gold was hid.

The people still believe that if they can get a white rabbit, and kill and eat it, they will be able to see where the gold lies hid:

Barney IVhelax, Drincy.

There is one side of the fairy chararter on which all the peasants are agreed; and that is their hatred of dirt and untidiness. Fairies have a particular avcrsion to the water in which feet are washed. This should therefore be carefully run out of the tub, and on no account thrown out of the door, for fear it might fall on any of them coming in. No dirty water may be thrown out after sundown; but if it is thrown out it is necessary to call: "Huga leat, huga leat, uisge salach!" Similarly it is forbidden to throw ash out after dark. 


\section{I70 Fairy Beliefs and other Folklore Notes}

The kitchen must always be cleaned up before being left at night, the fire raked, and a gallon of fresh water left for the good people. There are several tales told of the penalty paid for neglecting this duty. Here is one :-

Ketty Cassidy lived in Aughrim. One day her husband went to the fair, and there was no one left at home but herself. In the night, when she was in bed, there came in the full of the house of women, as she thought, and one of them got sick in the corner, and when the baby was born they went to look for clean water, but they had none to get, she had ne'er a drop in the house. One of them says: "What'll we do to wash the baby?" and they said: "What will we do but wash it in the churn that the buttermilk is in; and when she rises in the morning she'll know the odds of not leaving clean water within; and when she drinks it she'll find it worse."

Ketty. was looking on at all, and in the morning she ran home to her father's house, and she told them what happened. Her mother told her to go home, and to throw. out the buttermill, and to wash the churn, and not leave the track of milk on it, and never again to be without leaving clean water in the house. From that night out she never found one of them in it again.

ANNe Wuezan.

The fairies are a quarrelsome lot; in fact to this the safety of human beings from their wiles is sometimes due, since it is asserted that whenever a band of them is en. deavouring to capture a mortal, another band will generally try and thwart their rivals. The flat bottom known as Beirne's rock on the northern side of Lcitrim townland, Kiltubbrid parish, used in the olden time to be a favourite place of resort for the good people, and great fights used to take place there, the parties fighting all the way up the lonesome valley which lies between the townlands of Lisdrumacrone and Corglass. On Iisdrumacrone there was a house, now pulled down, where lived a widow 
woman and her young children. One night there was a great fight all up the hill between two bands of fairies, and the house coming in their way, they burst in at the back door and out at the front, fighting through the house. The woman was naturally greatly alarmed, and ran at once up to the room to see were her children safe. She found them quietly asleep, and in the morning all the doors were shut again. Some of the people say that she found a head under the bed, and that was the only evidence of the fight to be seen.

Mirciragl Lyxcit.

Many tales connect the fairies with the forts or round earthworks, and exhibit them as carrying on therein the details of everyday life:-

There were two neighbours, one a cooper and the other a farmer. They went out one day to plough; and the field they went to plough in ran up to a fort. They iwere ploughing some time, about an hour or so; and they heard the noise of churning in the fort, but they could not tell where the noise came from. They ploughed on for a bit, but every time they came up to the fort they heard the sound of the churning. It stopped after a little; and when they had gone down the hill and up again, there was a table there, and the churn staff, with the dash off it, left out to be mended, with cooper's tools laid' by. The cooper says: "Here's a job for me; you can plough till I get it mended for them." He set to work, and put the dash on the staff for them, and left it on the table, and went off to the other man to plough; and when they came back, the dash, table, and tools were all gone. The sound of the churning went on again for sometime after, and then it stopped, and a table was left out with oatcake and butter. The cooper invited the other to take some, but he wouldn't, and said it was not right. He went over and took some, and satisfied himself, and then went off to his plough again, 
and when they came back the table and oatcake were gone. When they had their ploughing and work finished for that day, they had to cross a little stream going home. They went riding their horses home, and the cooper went first and crossed the stream, but the horse of his neighbour, who was following him, shied when he was crossing and threw him, and broke his neck. It was said that the fairies were angry with him, because he would not take the food they offered him.

Edward MicVirtie, Cootehill, co. Caran.

I have referred to the power of the fairies to change themselves into any form they please. The following story of the "Fairy Midwife" type was told me to illustrate this:

Nurse Tinder was out one day with girls tying oats, when there came a big yellow frog in her way. She gave the frog a tip of her toe, and said: "That you mayn't be delivered of your burden till I'm at the delivery of you." Afterwards in a while, as she was going to bed, there came a knock at the door; and there was a fine horseman on a great steed, as she thought, a red-haired man. He told her to come away with him quick, for his mistress was in her confinement and wanted her. She said: "Where are you bringing me to?" and he said it made no matter, but to come on quick. So she got up behind him on the beast; and she says: "Will you leave me back again, for I won't know where to go?" "Oh yes," says he "you'll be let back." So with that, as they were going on near the castle, as she thought, the red-haired man says to her: "Neither eat nor drink anything when you go in here, nor take anything. She'll offer you money, but do not take it; but ask her to cure your daughter that's a cripple at home. And do not," says he, "mention God's name, for if you do you will have further to go with the castle."

When the baby was born, it was a man-child; and they were sverjoyed, the father and mother; and he came in 
like a lord dressed with gold buttons and all things fitting for a lord; and they brought in eating and drinking, and returned her many thanks. She thanked them, and said she was only after her supper, and couldn't eat or drink anything. "Well," says the mistress, "how much money will recompense you for your trouble when you'll neither eat nor drink." "None, at all, l'll take neither money or any payment; but I have a poor lame daughter at home; and if you can cure her l'll be for ever obliged to you."

The lady went in a great maze and paused for a while. "Nevertheless," then said she, "when you won't take money l'll do what you ask me. When you go home, look in your daughter's hough, behind, and you'll get a big needle stuck in it. One night I was airing my baby's clothes to the fire, and she annoyed me very much, for she blew the dust off the fire and destroyed my baby's clothes, and for that reason I did it to her. Little you thought," says she, "the day you gave the frog the tip of your toe, and wished it not to be delivered till you were there, that I was that frog; and that's the reason you were brought here to-night."

It was well for her poor daughter; for she'd never have got better, only her mother went that journey. She was left back home then, and took the needle out of her daughter's hough; and the girl was supple and happy for cver after.

For the reason above given frogs should never be illtreated. One does not know who or what may be in that shape.

ANNe Whelas, Driney.

\section{The Corragecn in Aghacashlaun.}

There is a fort in Aghacashlaun townland called the Corargeen. It is on a little rising ground, and is surrounded by bushes. Near this fort lived Frank - Onc night as he was going to bed there came a tap at the door; and on his 


\section{Fairy Beliefs and other Folklore Notes}

wife opening it she saw a little lad outside, who asked her for the loan of a hatchet and auger. She gave them to the lad, and shut the door. Some time after her husband asked her, did she know who the boy was? "I do not," says she, "but I think he was one of the neighbours' boys." "I hope they'll return the hatchet," says Frank. A fortnight went by, and nothing was heard of the hatchet and auger, and Frank began to be impatient. One night he wanted the hatchet for something and swore aloud that he'd never lend his things to anybody again. $\Lambda$ s he was speaking there came a tap at the door, and when they opened it there lay the hatchet and auger on the ground, but not a soul was to be seen. Next day Frank's eldest child slipped, in lifting the kettle off the fire, and fell down, and was so badly burnt that she died. He was then fully persuaded that the things were borrowed by the good people from the fort near the house to make the child's coffin, and "Dear knows," said he, "if I hadn't sworn at them, may be they'd have used them for something else." He did not live very long himself afterwards either.

Micirael Lyncir.

In addition I have noted the following :-

No mention should be made of fairies on Mondays or Thursdays. If you do mention them on those days you should say: "My back to them and my face from them."

If an oat-cake be baked and left for the next day it should have a piece broken out of it, and should not remain whole, because if the fairies came in the night and saw a wholc cake they would surely take it, but they would not touch a broken one, "or take your leavings." I This has now come to be applied to all cakes. Many of the old people used to leave potatoes ready cooked and

I The story of the "Ilorned Ilags" in Mr. O'Faherty's Siamsa an ghimkridh is told to account for this breaking of the cakes. 
pieces of bread for them of a night. In the morning these were given to the fowls and never eaten by the people of the house, because since it is, as it were, the spiritual part of the food that is taken, it would not be known whether the fairies had touched it.

If milk be spilt no annoyance should be expressed, but you should say: "There's a dry heart waiting for it," since the Good People may have been wanting it, and caused it to be spilt.

Should one come out of a house at night whilst eating, a portion should be thrown on the ground for the fairies.

I have referred above to the belief of the peasantry that the fairies are also inhabitants of the water as well as of the land. There are several local legends connected with Lough Allen which represent it as peopled by beings of a fairy nature. The following is one of these:-

\section{Legend of Lough Allen.}

There was a gentleman one time fishing on Lough Allen, himself and his boy. The lake was pure calm, but about the middle of the day he looked out before him, and he saw a great wave rising. As the wave was getting near them it was getting bigger and bigger; and they were greatly alarmed, and he did not know what to do. The gentleman in his trouble and fear took a dart he had in the boat and flung it with might and main at the giant wave. No sooner nor he did the lake became as calm as a boghole. The gentleman found himself greally fatigued, and struck for the shore, and as he landed on the shore he found he was hardly able to walk; so when he came to his own house that was over the lake on the hill, his mother asked him was he ill? and he said not, but that he was very fatigued, and that he'd go to bed for a while; "and if anybody comes in enquiring for me, tell them l'm out;" for he wanted to rest. 


\section{Fairy Beliefs and other Folklore Notes}

He wasn't very long in bed when a young woman who wasn't known in the neighbourhood, came in, and asked the woman of the house where was her son; and she said he was out. "Oh, no," says she, "for he's in his bed." "He is not," says the mother. "Indeed he is," says the young woman; and she says, "if you please tell him to get up, for that I want him, for I cannot go back without him." So the old woman went up and wakened her son, and he came down and asked the young woman what did she want.

She says: "Weren't you out fishing to-day on the lake? Do you remember the dart you flung at the big wave?"

"I do," says he.

"That's in my mistress's forehead," says she, "and nobody can take it out but your two hands; and if you do not come she will die before the sun sets, for nothing can take it out of her head but you; and if you come I promise to see you all right, safe and sound, back to your own home. I promise that on my knees," says she.

So the gentleman set off; and he travelled on, and he never saw a lake till he came back again, but he went on a beautiful road the whole way till he came to a palace at the bottom of the lake. His mother never left from the door till she saw them descend to the bottom of the lake.

As he entered the great hall he saw the queen sitting on her throne, and the dart in her forehead; and she welcomed him beneath the lake. She says: "You remember you were fishing to-day? You remember the giant wave that came to wreck your small boat?" "I do," says the gentleman. "Well, that wave was me," says she, "for I fell in love with you and thought I would have you in this happy home with me, and be my prince and lover for ever and a day; and when you saw the wave coming you were so frightened that you flung the dart with rage and might at $i t$, and that dart sank in my forehead as you plainly see; and nothing can take it out but your own two hands, but be sure 
to bring it at the first pluck, for you will not get the second, for I will die before the sun sets if you don't bring it at the first pluck."

So he grasped the dart tightly, and swept it at the first pluck from her forehead.

"Now," she says, "leave your hand on the wound, and it shall not bleed, and never shall there be a mark on it;" and he did so.

"What is your request ?" says she.

"Nothing," says he.

"You must have some request," says she. "Do you require gold?" "No," he says.

"Well, you must have some request and name it."

"All the request I'll ask of you is that anybody of my name, if they sailed across the lake in a washing tub, would not be drowned." So it was granted, and the queen reached him her jewelled hand, and bid him adieu, and told the woman to leave him high and dry at his own home; and so she did.

Ever since, while the name of him was to be had, he could sail in a pigin, and that was less nor a washing tub, and be safe.

IVILLIs Kixsey from TOM KiLROY of Glan, by the shore of the lough.

Another story told of this lake is of Taylor McAniff, who was one day taking potatocs across in a boat, when a woman put up her head and told him not to go that way anymorc with his potatoes, for that they were dirtying the clothes she had on her lines; and if he didn't take another route he'd mind it; and you may be sure he did.

\section{Bewitched Butter.}

1 have already given (Folk-Lore, vol. iv., p. 180, and vol. v., p. 184) several tales relative to the superstition that persons by aid of witcheraft can take the butter from 


\section{I78 Fairy Beliefs and other Folklore Notes}

their neighbours' milk. I have obtained the following additional notes under this head from John Ford of Kilclare townland, Kiltubbrid parish :-

One day a woman came to a house where cliurning was going on, and asked for a drink of water. It was given her; and as she was leaving she took a handful of salt from a plate on the table, where it stood ready to salt the butter, and went away on her knees from the door, dropping a pinch of salt in each cow-track, and uttering a cry as she went. The people of the house lost their butter during that year. To get it back they asked a man of the place who had a charm, to come. He put a wooden trencher on a stone in the dairy, and began to churn. No butter came. He did this three times, and on the third time none came, but when he entered the dairy, there were three small rolls of butter about one inch long on the trencher. These he put in the churn, and went on churning; and from that out the butter was returned to the house.

It is usual to refuse a light, even for a pipe, or even to give away anything out of a house, where churning is going on.

Should a man wish to take away butter from a neighbour, let him borrow his churn on May Day, throw a silver piece into the bottom of the churn, and churn. Then, on returning the churn, its owner will get no butter from it that year; but his butter will go to him who borrowed the churn.

\section{St. Martin's Day, inth November.}

It is an almost universal custom in the district on St. Martin's Day to kill some animal in his honour.

The actual practice varies slightly. In one case, a hen is killed, and the blood allowed to drip in the four corners of the kitchen. In another, it is sprinkled round the room, while out Drumkecran-way the blood is simply spilt any- 
where and covered up with turf-mould, or any other avail. able dust. The beast killed may be of any species, fowl, duck, goose, or even a kid; very rarely more valuable animals have been slain. A story is current of a man who, having nothing else, killed his only cow in honour of the saint, who rewarded him by increasing his riches in the following year, so that when St. Martin's Day came round again, he was the possessor of many beasts. Then in his plenty, he grudged even a fowl, and by the following I Ith November was as poor as ever he was.

In killing the victim they take it in their hands and slay it, saying: "I kill this [hen] in honour of St. Martin." The animal or bird so killed is always eaten by the family.

In this same connection it may be noted that when a family take possession of a house for the first time, a feast is given, and a hen (or something) is killed, and the blood sprinkled about for luck.

It would be interesting to know whether this honouring of St. Martin is an ancient practice, or whether it is a late cxplanation of a Samhain custom-kept on old All Souls' Day.

\section{Birth.}

The first water in which a child is washed should be burnt, or any water used by the nurse.

$\Lambda$ man is not allowed to take fire from a house where a woman is sick.

It is considered lucky for the woman to have something on belonging to the husband, as a necktic, \&c.

Some women wear a cord, called St. Francis' Cord, round the waist, since no one would die in childbed who wore one.

$A$ little bottle of holywater is hung up on the bed; the water is to be thrown over the room either by the husband or some woman whose last birth was a boy. 
A child, as soon as possible after birth, is turned three times over, "In the Name, \&c."

$A$ woman cannot be delivered if there is anything in the room, such as a press, which is locked.

If the umbilical cord, when it dries on a child, fall to the ground, the child will suffer from incontinence of urine. This may be cured by boiling a shrew-mouse in milk and giving the milik to the child to drink.

(The foregoing were communicated to me by a nurse who had noticed them in the course of her work amongst the people in the parish of Kiltoghert.)

The following are contributed by Mary Carty of Drumkeeran :-

If a woman about to become a mother sees a hare, the child will have a hare-lip, unless the woman immediately tear her petticoat. If she be accompanied by a man, and he can catch the hare and cut off its "scutty" (tail) all will be well.

A cradle must be borrowed for the first child after marriage.

\section{Marriage.}

After marriage the bride seldom goes home with her husband the same day, but often remains in her father's house for a week or more. Then the groomsman goes for her, and brings her to her new home; and once there she may not return to her father's house for a whole month, or she will have bad luck.

The bride is given away by the groomsman, and not by her father; and the parents seldom go to the church or chapel.

The fortune a man gets with his wife goes to form a wedding dower for his sister (if he has one), and is not considered to be necessarily the property of the newly-married couple. 


\section{Death.}

When a corpse is in a house, the clocks should be stopped and looking-glasses turned. If a cat or dog cross a corpse when it is laid out, the animal must be killed.

The water, towel, soap, ctc., used for washing a dead body are always thrown at the foot of some bush, and pushed in beneath it, so that they may rot away and not be used.

It is considered unlucky for a person to die on feathers. When, therefore, one is dying, he is lifted off on to a small straw bed. This after death used to be taken up to the top of $a$ hill and set on fire (apparently at night); and the neighbours would then know that a death had taken place. A funeral is always taken by the longest possible road to the graveyard.

\section{Cures, Erc.}

For a pain in the back.-Take the butt of a candle used at a wake, light it, and pass it three times round you.

For cpilepsy. -Take a crooked sixpence, a harrow-pin, a shirt (or shift), a lank of yarn; cut a little from the top of cach finger and thumb, and the tops of the hair, and bury the whole under the spot where the suffererfell; and he will never be amlicted again.

For ringworm. - Immediately a child is born, if a worm be placed in its hand it will have the power to cure ringworm. (This applies to any child; it is only the seventh son who can cure cvil). In the cure for ringworm, a cake is made, unknown to the person amlicted, and given him to eat in threc bites. $A$ plaster is also made of hen's excrement, the bark of ash (?) and tobacco; and the cure must be done on Monday or Thursday.

To prevent fever from spreading.-All the fires on the townland, and the two adjoining (one on each side), would be put out. Then the men of the three townlands would come to one house, and get two large blocks of wood. vot. vit. 


\section{Fairy Bcliefs and other Folklore Notes}

One would be set in the ground, and the other one, fitted with two handles, placed on top of it. The men would then draw the upper block backwards and forwards over the lower until fire was produced by friction, and from this the fires would be lighted again. This would prevent the fever from spreading.

Joun FORD, of Kildare, whose informant was an old woman.

Against witchcraft on May morning.-The first smoke from a chimney on May morning is apt to be used by witches for bringing bad luck on a house. This may be guarded against in the following way :-On May, eve, get a bunch of rowan leaves, and tie it up the chimney to dry, then on May morn, light this, and let that be the first smoke to go out of the chimney; for the witches can do nothing with it.

Francis Witelan, Driney.

\section{Miscellanea.}

Second marriage.-If a widower remarries, the second wife may not be brought, on entering her new home for the first time, through the doorway by which the first was carried out; for if the door be opened then, the spirit of the first wife must go out, and will meet the second wife and do her some harm. She must therefore be brought in through the other door of the house, or through the window. The dead woman's spirit will then continue in the house, and do no harm to the new comer.

IIair cuttings.-The Drumkeeran folk say that all cut. tings from one's hair should be carefully burnt, as, if the fairies get hold of them, they can work one harm. The same applies to nail-cuttings. Also, if hair-cuttings are thrown away, the owner will be required after death to travel everywhere in search of them.

$A$ different version is given at Kiltubbrid. There it is said that one should carefully keep every bit of hair cut, 
because on the Day of Judgement one will be weighed against the sins committed in the flesh, and one's very hair cuttings even may be required to turn the scale.

Washing hands.-Some people will not wash their hands in water that another has used, unless they first spit in it; otherwise the two would surely quarrel.

Drumkeeran.

Crowing hen.-The crowing of a hen is said to be very unlucky, and one so crowing would be killed at onceeither in the ordinary way, or by smothering or burning. "The worse way, the better."

Flax, hens' eggs or salt borrowed, and not repaid, will cause the borrower to wander after death, until he, or she, repay them.

Luck.-If a spark from a fire burn a hole in the front of your dress, your luck is said to be before you; but if at the back, your luck is behind you, and you will have none in the time to come.

$A$ house should never be swept out on the door, but up to the hearth; otherwise the luck will be swept out of the house. 